\title{
POESIA Y MEMORIAS \\ DE JOSEP CONANGLA I FONTANILLES \\ SOBRE LA GUERRA DE CUBA ${ }^{1}$
}

P O R

JOAQUIN ROY

University of Miami

En 1988 no sólo se cumple el Centenario de la aparición de $\mathrm{Azul}$, hito fundamental del modernismo, sino que también se conmemora el aniversario de la Exposición Universal de Barcelona en 1888, acontecimiento considerado como el inicio del modernisme catalán, del que es ejemplo mundialmente conocido la obra del arquitecto Antonio Gaudí. Modernismo y modernisme se hallan entrelazados con la labor de la llamada Generación del 98, cuya obra fue impelida por el desastre colonial de España en Cuba. Allí fue como recluta obligado un poeta catalán, Josep Conangla, cuyos versos (apenas conocidos) y memorias (totalmente inéditas) son fiel ilustración del modernismo hispanoamericano y catalán, al tiempo que su ideología es afín al 98.

Joan Maragall contesta en Barcelona, en 1904, una carta de un joven, retornado de Cuba después del desastre de 1898. Le había pedido unas palabras a guisa de introducción de su obra poética. Ve claramente el líder del modernismo catalán que los sentimientos del recluta repatriado (que narra líricamente su paso por la guerra) necesitan un vehículo muy diferente para completar la expresión de los hechos que dan base a las imágenes:

Muchas cosas que usted las ha sentido demasiado hirientes para poder decirlas con la santa serenidad de la poesía... y otras que las ha

${ }^{1}$ Este trabajo es una versión corregida y adaptada de la ponencia originalmente presentada en lengua catalana en el V Coloquio de la North American Catalan Society, celebrado en Tampa, Florida, los días 18 a 20 de marzo de 1987. Agradezco a la Directiva de la Florida Catalan Society y a la Universidad de Miami el apoyo. recibido. 
sentido demasiado con la cabeza para que salieran con la debida espontaneidad de la canción ${ }^{2}$.

Sesenta años después, el antes joven poeta, ahora ya anciano, construiría el puente que Maragall había señalado, el paso entre las cosas sentidas con el corazón (los poemas) y las generadas con la cabeza (el ensayo). Unas memorias todavía inéditas son, más que las crónicas de guerra, la glosa de los poemas. La inclusión hecha por el propio autor de las traducciones al castellano de sus versos (originariamente redactados y publicados en catalán) redondean su valor testimonial con una nueva luz sobre su estética poética.

\section{GÉNESIS DE UN POETA MODERNISTA}

La obra de Josep Conangla i Fontanilles (Montblanc, 1875-La Habana, 1965) es bien conocida por los especialistas del nacionalismo catalán por su actividad como presidente del Centre Català de La Habana, dirigente de otras instituciones catalanas de Cuba (como el Club Separatista N. ${ }^{\circ} 1$ y la Sociedad de Beneficencia de Naturales de Cataluña) ${ }^{3}$, director de La Nova Catalunya y como organizador de la Asamblea que culminó -el año 1928 con la aprobación de la famosa Constitución Provisional de la República Catalana, precisamente llamada «de La Habana» ${ }^{4}$, bajo la presidencia de Francesc Macià.

Periodista de profesión, corrector de estilo en el Congreso de Cuba, historiador, ensayista elegante, Conangla, sin embargo, no fue conocido bien como poeta. La conservación de sus memorias inéditas sobre la guerra de Cuba, donde estuvo como recluta forzoso, proporciona la necesaria luz a sus primeros poemas, reunidos en su libro tituado Elegía de la guerra $(1904)^{5}$. Después incluyó otros publicados en el breve volumen

${ }^{2}$ Carta-prólogo de Joan Maragall al libro de Josep Conangla i Fontanilles Elegía de la guerra (Barcelona: Tipografía Catalana, 1904), pp. 6-7. Excepto indicación contraria, todas las citas de escritos redactados originalmente en catalán han sido traducidas literalmente por el autor de este estudio.

${ }^{3}$ Para obtener un panorama de la evolución de estas sociedades, remito a mi trabajo titulado "Catalunya a Cuba: La Societat de Beneficència de Naturals de Catalunya», I Jornades d'Estudis Catalano-Americans (Barcelona: Generalitat de Catalunya/Comissió Catalana del Cinqué Centenari del Descobriment d'Amèrica, 1984), pp. 313-323.

${ }^{4}$ Véase nuestra edición titulada La Constitució de L'Havana i altres escrits (Barcelona: Edicions de La Magrana/Diputació de Barcelona, 1986).

${ }^{5}$ El título provisional fue Odes del cor (Odas del corazón). El subtítulo de esta. primera (y única) edición es Impressions de la Guerra de Cuba. Está dividido en 
titulado El meu pare, que al Cel sia... (1920) ${ }^{6}$; y finalmente recopiló otro volumen de prosa y poesía, Eternal (1921) ${ }^{7}$. El resto todavía está desperdigado por decenas de diarios y revistas de Cuba y España.

Elegía es el más consistente y compacto, tanto por su temática monográfica, su cariz autobiográfico, la sinceridad y rigor de su palabra como por el color y el sentido de la sonoridad, dentro de la tradición modernista más madura.

El modernismo catalán tiene afinidad con el movimiento global de la literatura de expresión castellana, pero se ubica en un contexto más amplio que engloba toda la expresión artística europea y que recibe diferentes nombres en distintos países (Art Nouveau, Modern Style, Stile Liberty, Style 1900). Su más típica exteriorización es la vertiente arquitectónica, cuya figura universalmente conocida es Antonio Gaudí, sobre todo a través de sus obras más espectaculares, como el Parque Güell, declarado en 1986 Patrimonio de la Humanidad. Pintura, escultura, literatura y urbanismo buscan en común (y por caminos separados) romper con la estética anterior: en contra de las líneas rectas, las curvas, la asimetría y las representaciones vegetales; ante las normas, la anarquía; la descripción da paso a la imaginación; la razón se ve desbordada por la pasión.

Si el modernismo literario latinoamericano se ve frecuentemente delimitado por la aparición de Azul (1888) y la muerte del poeta (1906) -aunque estas fronteras son arbitrarias-, el modernismo literario catalán ${ }^{8}$ se ciñe también pragmáticamente por la Exposición Universal de Barcelona en 1888 y la muerte de Joan Maragall en 1911, o bien se indica que va desde 1881 hasta la entronización del noucentisme en 1906. El latinoamericano y el catalán son afines, pero son productos de dos sociedades distintas. En Cataluña no solamente hay presupuestos estéticos, sino también ideológicos. Como los de expresión castellana, el modernisme compartirá un universo tangencial con la ideología regeneracionista del $98^{9}$.

tres partes: «Impresiones», «Recuerdos» y «Reflexiones». Algunas poesías fueron publicadas en Francolí, Joventut y otras revistas. El libro fue presentado con unas palabras de Francese Pi i Sunyer, presidente de «Catalunya Federal», el 20 de mayo de 1904.

${ }^{6}$ Montblanc: Imprenta Vda. Montblanc, 1920.

${ }^{7}$ Barcelona: A. Artís, 1921.

${ }^{8}$ Se recomienda la lectura del lúcido trabajo de Joaquim Marco titulado «E1 modernisme literari a Catalunya», capítulo introductor del volumen titulado también El Modernisme literari $i$ d'altres assaigs (Barcelona: El Punt/Edhasa, 1983), pp. 11-81.

${ }^{9}$ No es éste el lugar adecuado para aportar una bibliografía exhaustiva sobre el concepto de «generación del 98», pero sí conviene hacer un recordatorio mínimo de algunos textos, sobre todo los que tratan las conexiones con el entorno social y los que relacionan el «grupo» del 98 con los movimientos literarios contemporáneos o 
Reacciona contra la literatura de la Restauración y contra el naturalismo. Rechazará todo lo caduco y defenderá obsesivamente el papel activo de la juventud. Recibirá de la burguesía barcelonesa su mejor apoyo, pero comenzó como un movimiento de agitación artística.

Se identifica con las revistas $L^{\prime}$ Avenç ${ }^{10}$ y Joventut ${ }^{11}$, con gran confusión de criterios sobre los presupuestos estéticos. Reconoció como líderes a Joan Maragall y Santiago Rusiñol (del que no se sabe bien si era más pintor que escritor). Sustituyó los tradicionales Juegos Florales por las Festes Modernistes, en la tercera de las cuales, en 1894, el cartel anunciador es todo un manifiesto, pues se propone fundar un concurso literariopoético para cuidar el espíritu moderno, y si es posible, el futuro. Al mismo tiempo, advierte que es imposible negar que se acerca un renacimiento y una reforma de viejas formas, una vanguardia que recuerda los precedentes del Renacimiento. Este plan de convertirse en "vanguardia» sería acaparado por el futurismo.

Josep Conangla se forma en ese ambiente. Justamente antes de salir para Cuba por primera vez, es el iniciador de una polémica amistosa entre algunos de los más destacados protagonistas del movimiento modernista. Las páginas de unos periódicos de Sitges y Tarragona sirven de fondo. Son los mismos momentos de auge de las fiestas modernistas.

sucesores: José Luis Abellán, Sociología del 98 (Barcelona, 1973); Azorín, "Aquella generación», La Esfera (Madrid), 25 abril 1914; «La Generación del 98», Obras completas, II (Madrid, 1947), pp. 896-914; Pío Baroja, Tres generaciones. Obras completas, V (Madrid, 1948), pp. 574-580; Guillermo Díaz-Plaja, Modernismo frente a 98 (Madrid, 1951); Estructura y sentido del Novecentismo español (Madrid: Alianza Editorial, 1975); John Englekirk, «El hispanoamericanismo y la generación del 98», Revista Iberoamericana, II (1940), pp. 321-351; Pedro Laín Entralgo, La generación del 98 (Buenos Aires, 1947); Luis S. Granjel, La Generación literaria del 98 (Salamanca: Anaya, 1966); Juan López-Morillas, Hacia el 98: literatura, sociedad, ideología (Barcelona, 1972); "Preludio del 98 y literatura del desastre», Modern Language Notes (1962), p. 179.

${ }^{10}$ Fundada en Barcelona por Jaume Massó i Torrents. Apareció con periodicidad quincenal o mensual en dos épocas, entre 1881 y 1884 (época en que se definía como difusor del positivismo) y de 1889 a 1893 (etapa en que se concentra en el fenómeno artístico, dirigida inicialmente por Ramón D. Parés y con la colaboración de Apel.les Mestres, Narcís Oller y Josep Ysart, y luego bajo el predominio de Santiago Rusiñol, cuando se convierte en una publicación polémica, nacionalista y anarquizante).

${ }^{11}$ Seminario catalanista publicado en Barcelona entre 1900 y 1906, bajo la dirección de Luis Vía y Alexandre de Riquer, afín a la «Unió Catalanista», que fomentó el activismo cultural y se convirtió en el vehículo más representativo del modernismo. 


\section{MOTOR DE UNA POLÉMICA}

Conangla abrió el intercambio con el artículo titulado «Modernismo», que resumía su posición contra el arte neoclásico, la repetición, el plagio y la vulgaridad. Ignasi Bó i Singla ${ }^{12}$ decía en «Sobre el Modernismo»:

Pierde la patria y entrarás en el arte; haz como la leyenda espiritista, purifica tu inteligencia, deja preocupaciones y avanza, avanza, que ya avanzaremos puros de ánima y fuertes de corazón, a juntarnos al gran todo, al dios impersonal e innominado de la belleza.

Josep Aladern ${ }^{13}$ continuaba en «Más sobre el Modernismo»:

Conangla admite la patria como base de un arte moderno, y tú, amigo Bó, le dices que pierda la patria y entrará en el arte. No estoy de acuerdo; muy al contrario, creo que la idea y el sentimiento de la patria es un gran elemento para el arte moderno... Ibsen es grande siendo noruego; nosotros lo podemos ser como catalanes... Es una quimera la creación de un arte universal, que a la fuerza tendría que resultar híbrido, sin color y sin vida.

En el artículo siguiente, «Aclaración», Conangla le daba la razón:

El modernismo en sí, espurgado de ramificaciones, no es otra cosa que la tendencia viva hacia las nuevas formas, hacia los nuevos ideales artísticos. Estas formas e ideales pueden ser abrazadas al igual por Ibsen y su grupo que Rusiñol y sus elementos... todos pueden adherirse a este concepto, a la anarquía intelectual que nos proponemos.

Gaya Guardiola señalaba en «Cuatro palabras»:

Juzgo, pues, imposible perder la patria; es más: creo que no necesitamos perderla para entrar en el arte. El arte tiene que ser inmenso, abrazar a los seres de todas las razas.

12 Barcelona 1872-1923, periodista y tipógrafo. De ideología republicana federal, fue director de La Autonomía, de Reus.

${ }^{13}$ Josep Aladern fue el seudónimo usado por Cosme Vidal i Rosich (Alcover 1869-Barcelona 1918). De ideología republicana y federal, fue el dirigente del $\mathrm{Mo}$ dernisme en Reus. Fundó las colecciones «Lo Modernisme» y «Foc Nou» y la revista Almanac Modernista de la Literatura Catalana. Se cree que fue el autor del manifiesto-anuncio de la Tercera Fiesta Modernista de Sitges en el año 1894. 
P. Redón ponía la nota discordante con su artículo titulado «Chiflados":

Primer síntoma de chifladura: el prurito y casi exigencia de que se escriba en catalán... hasta ahora nadie me ha convencido ni veo en ello la ventaja o utilidad de escribir en catalán... un nuevo fanatismo: el catalanismo ${ }^{14}$.

Aladern, naturalmente, le contestaba con «Autonomía en todo»:

Todos los que escriben en su lengua son chiflados; lo fue Cervantes, porque escribió Don Quijote; lo fue Shakespeare, porque escribió tantos dramas en inglés; lo es Ibsen, porque escribe en noruego.

Ruiz y Porta ${ }^{15}$ hacía una comparación entre el modernisme y los anteriores movimientos en su nota titulada «Epístolas»:

El escritor realista, por ejemplo, hacía sus cuadros demasiado del natural. Lo copiaba todo tal como la naturaleza lo presenta. ¿Frío? ¡Frío! ¿Triste? ¡Triste! Pero nada se veía del alma del artista. No hacía el arte abstracto del corazón, que es como el arte debe practicarse. Lo decía solamente con los ojos y con el cerebro. El realismo es un arte no sublimado por la fantasía del artista. Deja el corazón vacío, frío, impasible casi, sin emociones. El Modernismo es el arte nuevo, moderno... El realismo es todo cerebro; cerebro solo; y el Modernismo es cerebro y corazón, todo de una pieza. El realismo mira tan solamente a la Tierra; a la Naturaleza. E1 Modernismo, sin dejar de mirar a la tierra, mira también al cielo; a lo infinito.

El artículo central sería, naturalmente, el de Rusiñol, titulado «Conversación». En primer lugar, denuncia el aislamiento de las clases sociales de Cataluña:

¿Cómo puede la gente adinerada saber qué es el arte si no se relacionan más que entre ellos, y cómo pueden saberlo los pobres si no tienen ejemplos, ni esperanzas de gloria, ni estímulo de recompensas? Nuestra tierra, para el arte y para muchas otras cosas, todavía está verde para costumbres modernas; todavía es una criatura, si bien una

${ }^{14} \mathrm{El}$ original está en castellano.

15 Tarragona 1866-Barcelona 1934. Periodista de ideología conservadora, fundó la Liga Regionalista. Fundador del diario Lo Camp de Tarragona y director del Butlletí Arqueològic y del Diario de Tarragona, fue archivero de la Mancomunitat de Catalanya y presidente del Centre Excursionista (1923-25). Fue autor de la Monografía del Cau Ferrat (1895). 
criatura con dientes y arrugas de vejez; todavía está ensimismada sobre hermosos laureles, laureles ganados hace tiempo y resecos, aunque todavía olorosos, que parecen que desprendan una morfina adormecedora. nismo:

A continuación no encuentra una definición ${ }^{16}$ precisa para el moder-

Es como una mujer hermosa, de la que se admira su hermosura, sin poderla definir; es como el aire que pasa, embalsamado, que el corazón lo huele y que el cerebro no puede explicar. Es más amor que conocimiento... Modernismo para mí quiere decir que se acerca; el arte que desean los unos y los otros temen; el arte que hoy se ha de empujar para hacerlo pasar por el empuje de las grandes multitudes, y que mañana será viejo ... después de una decadencia, viene el ascenso; después del realismo, el idealismo; después de los correctos clásicos, los exagerados románticos; después de los realistas, los espiritualistas... Este modernismo que nos preocupa no es una moda, no es un afán de estar al corriente de las últimas evoluciones, es una fuerza que nos empuja con alas blancas de esperanza... es el hombre estirando el cuello, mirando allá... imán que chupa a los que anhelamos lo que vendrá y empuje que hace continuar a los que se los lleva río abajo, lo que los hombres levantan, aterrizan, restauran y arruinan con una fuerza desconocida que nos pide un más allá, la idea nueva de una florida primavera... El modernismo de hoy es individualista, con hojas espirituales... El modernismo de hoy es la libertad en el arte: que cada uno haga lo que sienta y el corazón le dicte, pero que sea sincero... El brote de hoy tiene de la mística lo que el misticismo tiene de sufrimientos y visiones; tiene de anarquista lo que la anarquía posee de fantasía imposible; tiene de revolucionaria ideal, por la poca fe en las prácticas humanas ${ }^{17}$.

En el broche final, titulado «Finis...», Conangla invitaba a todos a participar en la Sección Modernista de El Francolí: «Donde podremos todos los soldados fervorosos de estas ideas depositar el grano de arena para el gran edificio que se proyecta.» Firmaba estas líneas el 30 de marzo de 1895 en Montblanc. Pocos días después, sin embargo, le llegaba el reclutamiento forzoso que traumatizaría su carrera literaria y su evolución modernista.

${ }^{16}$ Ramón Planas, en El Llibre de Sitges (Barcelona: Editorial Selecta, s/d.), se refiere a la encuesta y la definición de Rusiñol: «cualquier parecido con la teoría maragallesca de la palabra viva, el elogio de la espontaneidad y de la sinceridad que Joan Maragall había de lanzar ocho años más tarde».

${ }^{17}$ El Francolí, 30 de marzo. 


\section{UN POEMARIO BIEN RECIBIDO}

Aunque de circulación limitada, tuvo una buena acogida en las páginas culturales y literarias de los diarios y revistas de su tiempo ${ }^{18}$. Los críticos y poetas Carles Rahola y Antoni Rovira i Virgili hallaron afinidades con la obra de Emili Guanyabens ${ }^{19}$ e Ignasi Iglesias ${ }^{20}$ (además de Maragall ${ }^{21}$ ). Rovira señalaba la evolución de la poesía de Conangla dentro, incluso, del propio libro: «Compárense los versos que forman el cuerpo principal del libro, escritos en Cuba hace seis años, con la introducción y la 'Ofrenda', escrita hace pocos meses» ${ }^{22}$. Bó i Singla decía en El Pacto: «Otras guerras coloniales han proporcionado honores y riquezas. Nuestro amigo, un ramillete de poesías. No ha cantado en ellas el honor de la victoria ni ha llorado quizá merecidas derrotas» ${ }^{23}$. Carles Rahola (con el seudónimo de Panida) afirmaba en El Autonomista: "Hay un amor y un odio que baten sin cesar las alas, dejando un rastro luminoso y una huella roja: el amor a la fraternidad, el amor a la bondad, el amor al amor; el odio a la guerra, al mal, a todo lo que significa esclavitud, depresión de la personalidad humana, infelicidad; el odio al odio» ${ }^{24}$. El poeta gallego Curros Enríquez, en el prestigioso Diario de La Marina ${ }^{25}$, declaraba en

${ }_{18}$ Además de los citados directamente en el texto, el archivo Conangla contiene copias de otras magníficas reseñas de este libro: A. Palau i Dulcet, La Conca de Barberà (Montblane, 21 mayo 1904); La Veu de Catalunya, 28 mayo 1904; El Diluvio (25 mayo 1904); Antoni Rovira i Virgili, La Avanzada (Tarragona, 28 mayo); Arnau Martínez y Seriña, Joventut (Barcelona, 2 junio 1904); Alfredo Opisso, La Vanguardia (Barcelona, 3 junio); P. Redón, La Justicia (Tarragona, 4 junio); E. Moliné y Brasés, La Renaixensa (Barcelona, 5 junio 1904); J. Mallafré, El Programa (Barcelona, 4 junio 1904); Resumen Bibliográfico (mayo 1904); Rata Sabia, La Esquella de la Torratxa (Barcelona, 10 junio 1904); Diario de Albacete; La Democracia de Olot (19 junio); Román Jori, La Lucha (Girona, 18 junio); Francesc Martí, El Igualadino (19 junio); Germinal (Sabadell, 2 julio); J. M. Mallafré, La Defensa (Barcelona, 1 julio); Francesc Pi i Arsuaga, El Nuevo Régimen (Madrid, 9 julio); E. González, Llevor (Sant Feliu de Guixols, 24 julio); Joan Ruiz i Porta, El Camp de Tarragona (5 nov.); Manuel Morplu, El Comercio (La Habana, 4 junio 1905).

${ }^{19}$ Concretamente, Rovira señala la afinidad con Volianas (La Avanzada, Tarragona, 28 de mayo).

` Sant Andreu del Palomar 1871-Barcelona 1928. Fue destacado autor teatral, influido por Ibsen y Maeterlinck, muy conocido por sus dramas de denuncia social, colaborador de L'Avenç. Recibió la Flor Natural en los Jocs Florals de La Habana de 1923, organizados por Conangla.

${ }^{21}$ El Autonomista (Gerona, 19 junio 1904).

${ }^{22}$ La Avanzada (Tarragona, 28 mayo 1904).

23 Barcelona, 21 mayo 1904.

${ }^{24}$ Gerona, 12-19 junio 1904.

${ }^{25}$ La Habana, junio 1905. 
una sintética nota: "Palpita honda inspiración y un tierno afecto a las cosas de Cuba» ${ }^{25}$. Antonio Andreu Cabestany le recomendaba: "Persevere, persevere, que la causa de la justicia y de la razón ganará mucho» ${ }^{27}$. Joan Maragall, en la ya mencionada carta ${ }^{28}$, que servía de introducción al poemario, decía: «No me extraña nada su deseo de ver plasmado en un libro aquella serie de momentos de su espíritu que seguramente permanecerán como los más fuertes de su vida» (p. 6).

En unas líneas cortas resume el contenido y el origen de los poemas:

El peligro de la propia existencia, los amores más santos dolorosamente truncados, el sentimiento de patria exaltado por el forzado alejamiento, el instinto humanitario brutalmente contrariado, la flor de la juventud magullada, ¿qué no sufre en usted, entonces, qué no grita, qué no 1lora, qué no espera? (p. 6).

Los hechos históricos ${ }^{29}$ de la guerra de 1894 a 1898 , base de los poemas, se encuentran fielmente reflejados en las doscientas páginas de sus «Memorias», que quedaron inéditas después de la Revolución del 58.

${ }^{26}$ La Habana, junio 1905.

${ }^{27}$ El Nuevo Ideal, Mataró, 4 junio 1904. Original en castellano.

${ }^{28}$. La correspondencia con Maragall continuó después de la segunda marcha -esta vez voluntariamente- de Conangla hacia Cuba en 1905. Eternal -el volumen de prosa y poesía - contiene una carta de Maragall contestando la despedida de Conangla desde La Habana: «Le deseo prosperidad y gloria en esas tierras de libertad» (Barcelona, 18 febrero 1906, p. 30). Conangla publicó un libro sobre la poesía de Maragall: Els altres sentits (Mèxic: Editorial Xaloc, 1957), con versión al castellano Los otros sentidos: Resonancias del 'Canto espiritual' de Maragall, sobretiro de Revista de la Biblioteca Nacional de Cuba (abril-junio 1957).

${ }^{29}$ Entre las obras de cariz histórico o interdisciplinario sobre el conflicto hispanocubano se recomiendan las siguientes: Roberto Mesa, La idea colonial en España (Valencia: Fernando Torres, 1976), antología de muestras de la ideología española hacia América; José Manuel Allendesalazar, El 98 de los americanos (Madrid: Cuadernos para el Diálogo, 1974), una revisión del conflicto siguiendo las fuentes norteamericanas; Ricardo de la Cierva, Historia básica de la España actual (Barcelona: Planeta, 1974), un divulgativo panorama de los dos últimos siglos de historia de España; Raymond Carr, España, 1808-1939 (Barcelona: Ariel, 1966), uno de los mejores ejemplos de historia objetiva redactada por un profesor británico; Melchor Fernández Almagro, Historia politica de la España contemporánea (Madrid: Alianza Editorial, 1968-74). Tomo II: 1885-1897; Tomo III: 1897-1902, entre los más respetados tratados; Miguel Martínez Cuadrado, Historia de España Alfaguara, tomo VI: La burguesía conservadora (1874-1931) (Madrid: Alfaguara/Alianza Editorial, 19731976). 


\section{LA CRÓNICA DE LA POESÍA}

Este primer volumen de sus «Memorias» ${ }^{30}$ (que fue el último, pues Conangla no tuvo más fuerzas para organizar los demás, apenas esbozados en notas y recortes encarpetados) cubre, casi de una forma magnetofónica, sus sentimientos durante los años que sirvió en Cuba durante la guerra de 1895 a 1898. Rebasados los ochenta años, Conangla incluso conserva el tono de redacción propio de los escritos juveniles, más la precisión del mejor periodismo descriptivo y de la comunicación peculiar de los partes militares. La voz narrativa no es la de un viejo catalán que escribe en castellano, sino la de un inexperto recluta español que revela en sus líneas su registro honesto de los acontecimientos que pasan a su lado. Más claramente en algunas páginas que en otras, parece que la redacción hubiera sido hecha no en 1958, sino a finales del siglo xIX. En lugar de ser escritas en su casa del barrio habanero del Vedado durante los años cincuenta, las «Memorias» parecen transcripción de las notas que Conangla hubiese tomado en el buque que lo llevó de retorno a España en 1898.

Dejando de lado el lenguaje evolucionado después de decenios de periodismo, textos nacionalistas de toda clase, ensayos históricos escritos en correcta lengua, las «Memorias» son el registro de la conciencia histórica. En una prosa arcaizante, con unos párrafos que a veces son peligrosamente largos, incluso usando normas ortográficas ya mucho tiempo atrás abandonadas tanto en Cuba como en España, parecería que Conangla se transfigurara: borra toda su experiencia de hombre maduro y con las espaldas cargadas de años, y quiere escribir como lo haría aquel recluta temeroso que salió de Montblanc en 1895.

Después de la estadía en Cartagena, Conangla embarcó, «sucio, desastrado y lleno de miseria» ${ }^{31}$, en el vapor «San Francisco», de la Compañía

${ }^{30}$ El título completo del original que se conserva en los archivos de la familia Conangla es «Memorias de mi juventud en Cuba durante la guerra separatista (1896-98)». Todos estos materiales fueron cedidos a la Florida Catalan Society, para su conservación y uso académico, el día de Sant Jordi, 23 de abril de 1986.

${ }^{31}$ Las pésimas condiciones del traslado de las tropas hacia Cuba está mejor documentado por anónimas descripciones, excepciones minoritarias en la cupletería patriotera de aquellos días:

$$
\begin{aligned}
& \text { «Del castillo de proa a la bodega } \\
& \text { revueltos, confundidos, hacinados, } \\
& \text { la nación 'empaqueta' sus soldados } \\
& \text { y a la implacable muerte los entrega.» }
\end{aligned}
$$

(El Domingo, 23 enero 1897; véase el poema completo en la edición de García Barrón, p. 114). 
Trasatlántica, que llegó a la bahía de Cienfuegos, en Cuba, el 11 de diciembre. Transferido al remolcador "Antinógenes Menéndez», finalmente llegó a Tunas de Zaza, en la costa sur de la isla, muy cerca de los horrores de la guerra. Su expedición era una de tantas de quintos. El general dimitido Arsenio Martínez Campos ${ }^{32}$ había recibido más de 80.000 hombres. Los insurrectos habían comenzado la llamada marcha de la «invasión» y traspasaron la provincia de Matanzas para entrar en la de La Habana y acabar, el día 22 de enero de 1986, con la toma de Mantua, el lugar más occidental de la isla. El día 10 de febrero llegó el general Valeriano Weyler ${ }^{33}$ con otra expedición de más de 21.000 soldados. Estas tropas, sumadas a los voluntarios y la milicia, hacían llegar el número de soldados españoles a más de 200.000 , contra 30.000 insurrectos. Eran los días de la política suicida, «hasta el último hombre y la última peseta».

Conangla narra la guerra desde dentro, pero no canta los combates como lo haría un cronista clásico de guerra, sino que se convierte en un testigo especial de la represión interna. Un aspecto ambiental de su pintura destaca en todo momento: el contrapunto entre las escenas de guerra y el refugio que para él representan el periodismo y la creación literaria.

${ }^{32}$ Segovia 1831-Zarauz 1900. Sirvió en Africa (1859-60), luchó en Cataluña contra los carlistas. El 29 de septiembre de 1874 proclamó rey de España a Alfonso XII. Presidente del Consejo de Ministros, fue capitán general de Cuba anteriormente y firmó la Paz de Zanjón en 1877.

${ }^{33}$ Palma de Mallorca 1838-Madrid 1930. Descendiente de familia prusiana, fue voluntario en Cuba tempranamente, en 1863. Sucesivamente fue capitán general de Valencia, Canarias, Baleares, Filipinas y Cataluña, para pasar a Cuba en 1896, de donde pidió ser relevado en 1897. Ministro de la Guerra en varias ocasiones y senador vitalicio. Su fama de «duro», sobre todo en Cuba y Filipinas, le valió justamente la animosidad de sus contrincantes y el temor en España. Los archivos de Conangla conservan este soneto vitriólico atribuido a don Ricardo del Monte (Cimarrones 1830-1909), escritor y político cubano:

«Mirada de reptil, cuerpo de enano, instinto de chacal, alma de cieno; hipócrita, cobarde, vil y obsceno como el más asqueroso cuadrumano. Un tiempo azote del país cubano, fue a todo noble sentimiento ajeno, y hoy al mismo SATÁN convierte en bueno esta excrecencia del linaje humano. Ruina, desolación, hambre y miseria las obras son que a ejecutar se atreve este horrible montón de vil materia. $\mathrm{Y}$ a un monstruo tal, con intención aleve, el gobierno de Cuba encarga Iberia, al expirar el siglo diez y nueve!» 
Cerca del campo de batalla, dentro del escenario de la reconcentración ${ }^{34}$ decretada por Weyler, todo es sangriento, negativo. En la redacción de los diarios, dentro de los ambientes literarios de las peñas, en la soledad de su escritorio, todo respira paz. Una paz ausente, en realidad, en aquel tiempo. Una paz que Conangla busca con ansiedad en las conversaciones con los precisos y contados protagonistas honestos de sus memorias: algunos militares que él considera justos, algunas familias cubanas y españolas que merecen su respeto. Es una narración maniquea, de buenos y malos: el pueblo cubano independentista (o silenciado) y las autoridades coloniales españolas. En el medio hay un pueblo español engañado y unos (pocos) militares profesionales que tratan de cumplir con su deber; los que de veras más pagan las consecuencias son los reclutas españoles.

El tema de las «Memorias» es la guerra, pero no son crónicas bélicas; son sobre la amistad, hablan del contraste entre la guerra y la paz, precedente de su prosa ensayística contra el colonialismo y la monarquía; son descripción y comentario sobre aquel tiempo. No son recuerdos de un participante activo en la contienda, sino testimonio ofrecido desde dentro, pero conservando una cierta distancia; son apuntes de un recluta que no quería estar en aquella tierra dentro de aquella guerra absurda: trata de representar a miles de jóvenes que perdieron la inocencia, la salud e incluso la vida en la manigua cubana. Es un precedente de la objeción de conciencia — sin los mecanismos prácticos - antes de que ésta se convirtiera en pauta cotidiana en todas las guerras que siguieron. Conangla había salido de Cartagena hacia Cuba, casi musitando palabras de habanera: «Adiós, que el deber me llama, adiós, que me voy a La Habana, a luchar, a luchar por la Nación... fue por obligación» ${ }^{35}$. Estas «Memorias» son, sobre todo, por lo que atañe a su naturaleza literaria, una glosa necesaria de su poesía, desconocida, cubierta en la tradición nacionalista de Cataluña por la fama de sus escritos independentistas, aislado de la corriente central de la poesía catalana debido a la distancia, limitada a unas ediciones prácticamente privadas. Esta poesía se divide en tres maneras o actitudes poéticas: descriptiva, meditativa y nostálgica. Dentro del contexto de las letras hispánicas, la poesía de Conangla incluida en Elegía debe ser

${ }^{34}$ Recordemos el texto del bando de 21 de octubre de 1896: «(1) Todos los habitantes en los campos o fuera de la línea de fortificación de los poblados se reconcentrarán, en el término de ocho días, en los pueblos ocupados por las tropas. Será considerado como rebelde y juzgado como tal todo individuo que, transcurrido ese plazo, se encuentre en despoblado; (2) Queda prohibida en absoluto la extracción de víveres de los poblados y la conducción de uno a otro por mar o por tierra sin permiso de la autoridad militar del punto de partida. A los infractores se les juzgará y penará como auxiliares de los rebeldes.»

${ }^{35}$ "Adiós mi península hermosa», habanera tradicional. 
considerada como plenamente modernista por su lenguaje, imágenes, color. Pero no se trata de una poesía solamente colorista de la primera época del movimiento en América Latina, sino que hace uso de las mejores técnicas de la «escuela» para conseguir comunicar todo lo que entonces le atormentaba. En cuanto al contenido, se ubica en la dirección crítica del 98 temprano, minoría disidente que indaga acerca del cáncer social y político que ha producido el desastre: es una respuesta impotente ante el patrioterismo que ha envenenado la conciencia popular ${ }^{36}$. En la arquitectura de las «Memorias», Conangla ubica estratégicamente sus poemas para conseguir el efecto contrario: son la glosa del texto narrativo y autobiográfico; la poesía es el testimonio de las memorias, sirven para explicar sus sentimientos cuando precisamente transcurrían los hechos que se narran (o inmediatamente después) o para exteriorizar la angustia por la nostalgia de la tierra abandonada al otro lado del Atlántico. E1 lector repasa los acontecimientos más característicos de la época, al tiempo que se invita a efectuar un paseo por la poesía del autor. Ensayo y poema se unen. E1 discurso narrativo ${ }^{37}$ culmina con la denuncia de los horrores de la guerra; el anticlímax es la inclusión de los poemas ofrecidos directamente en su versión personal en castellano.

\section{GLOSA DE UNA GUERRA}

Obligado a ir a Cuba, primero como excedente de cupo y luego por ser incluido en un batallón expedicionario a causa del alzamiento históricamente conocido como «Grito de Baire», Conangla dejó en sus «Memotias» esta exacta, impresionante y plástica imagen de Cartagena:

${ }^{36}$ Recomendamos una obra fundamental, pionera y documentadísima, repleta de ejemplos de poesía popular publicada en una decena de periódicos de la época: Carlos García Barrón, Cancionero del 98 (Madrid: Cuadernos para el Diálogo, 1974). Introducción de Roberto Mesa, «Mitología del 98», pp. vrr-xvi. También conviene la consulta de Miquel del Sants Oliver, La literatura del desastre (Barcelona, 1973); el texto divulgativo de Fernando Díaz-Plaja, 1898 (Madrid: Editora Nacional, 1976); y José María García Escudero, «El Parlamento ante el desastre», Arbor (1948), p. 402.

${ }^{37}$ Uso expresamente la terminología empleada para clasificar las crónicas del descubrimiento, conquista y colonización en algunos textos críticos recientes. Como ejemplo, recomendamos la obra de Beatriz Pastor Discurso narrativo de la conquista de América (La Habana: Casa de las Américas, 1983). Más cuidadoso y erudito, pero en la misma línea, que consiste en alinear las crónicas con el modo narrativo, es el libro de Enrique Pupo-Walker La vocación literaria del pensamiento en Amé-. rica (Madrid: Gredos, 1982). 
E1 embarco fue a media mañana del 23 de noviembre de 1895, en el puerto de Cartagena, la ciudad caliginosa y amurallada de los cuarteles, de los hospitales, de los arsenales y de las atarazanas; la frívola ciudad españolísima donde a cada paso se ven militares de todas las jerarquías, grupos de soldados y cabos de todas las armas, sargentos fanfarrones, asistentes y ordenanzas portando grandes cestas; la ciudad de la Feria y del Molinete, de los Cafés clásicos y de las tiendas de reventas; de los churros y de los higos chumbos, del pescado frito y de las sandías sangrantes y tragantes.

Cartagena, en aquel día, como en todo el año, estaba impregnada del fuerte olor a nardo; olor sugestivo que durante los cinco meses de mi permanencia en el recinto cartagenero fue un bálsamo para las tribulaciones espirituales que me arrancaron de mi tierra nativa. Pero aquel olor penetrante lo absorbí con influencia más turbadora cuando mi batallón, forzosamente expedicionario, bajó de su cuartel desde las alturas de la ciudad, dirigiéndose al muelle en recorrido por las calles, entre colgaduras y flecos de colores, sones de músicas destempladas, vítores estúpidos, palmoteos y griterías ensordecedoras.

Con el enfoque de esta descripción, conviene referimos ahora al comentario, inadvertido en su momento, de Antoni Rovira i Virgili sobre unos poemas concretos ${ }^{38}$ de Conangla en ese mismo libro: «El poeta ve pasar delante de sus ojos llorosos, con visión cinematográfica, cuadros animados de la tierra añorada» ${ }^{39}$. Es importante, sin embargo, la anotación, por doble motivo. En primer lugar, porque en aquel tiempo todavía no se había convertido en tópico referido a las descripciones dramáticas, llenas de movimiento y vida propia, con el vocablo cinematográfico, referente a lo que luego sería reconocido como «el séptimo arte», apenas en la infancia en 1904. Habrá que prestar la debida atención, sin embargo, a este comentario aislado. Conangla, medio siglo antes de redactar sus «Memorias», así había descrito la impresión de la despedida de Cartagena, en el poema titulado «El embarque», incluido en Elegía de la guerra:

Tengo el cuadro inolvidable siempre vivo en mi cerebro:

En tropel, las muchedumbres circundaban todo el puerto.

Despedidas sollozantes, abrazos y dulces besos; palabras entrecortadas,

${ }^{38}$ «Soñando con mi tierra», «Recuerdos invernales», «La retama», «Remembranza» y "Padre», cuyo contexto se alude más adelante.

${ }_{39}$ La Avanzada, 28 mayo 1904. 
gritos, ayes y lamentos;

desimayos, crisis nerviosas, promesas y juramentos; manos trémulas, en busca de otras manos en sustento... Rebaños de hombre, sin tino; y por contraste siniestro, Marcha de Cádiz ${ }^{40}$ sangrienta, discursos de engaño huero, casacas condecoradas que del muelle no salieron; pitazos del buque astroso que humeaba ya en el puerto; y el crujir de las cadenas entre adioses sin consuelo!...

Todo pasó. Gritos roncos se desataron, frenéticos. Después, tan sólo siluetas de aletear de pañuelos cada vez más esfumadas, se agitaban a lo lejos!... ${ }^{41}$

Si Rovira pensaba que allí se usaba técnica cinematográfica, no iba: desencaminado; es más, el fragmento de las memorias y el poema recuerdan el retrato de una filmación de un documental, más concretamente tele-

${ }^{40}$ Esta marcha militar se había iđentificado con el patrioterismo. Famosa es la frase de Blasco Ibáñez: «Esa odiosa y fanfarrona Marcha de Cádiz», con la que Julio Burell estructuró un antológico artículo titulado «La gran muerta» (Heraldo, 18 septiembre 1898): «Suena mal en nuestros oídos; resulta odiosa, su alegría es un remordimiento. Fue un himno electrizante y enloquecedor, y es hoy sencillamente una desvergiienza musical... La Marcha de Cádiz no debe ser la Marcha fúnebre de los repatriados» (transcrito por Fernando Díaz-Plaja, 1898 [Madrid: Editora Nacional, 1976], pp. 133-134).

${ }^{41}$ Traducción del autor del poema original «L'embarch» (p, 18). Véase la similitud de esta escena lírica con los siguientes versos de Maragall:

"Yo vi barcos zarpar repletos

de hijos que a la muerte entregabas;

sonriendo iban hacia el azar

y tứ cantabas junto a la mar

como una loca.»

(Versión del original catalán de la «Oda a España», por Joaquim Molas y Josep M. Castellet, en Ocho siglos de poesía catalana [Madrid: Alianza, 1969], p. 406; sobre el tema de España en la obra de Maragall, remito al lector al libro de Mercedes Vilanova España en Maragall [Barcelona: Penínstıla, 1968]). 
visivo. Conangla toma la misma distancia de los acontecimientos que la adoptada por un cameraman de cadena de televisión. Pero, además, naturalmente, en la secuencia de la narración, los sentimientos íntimos deben ser también plasmados. Momentos antes, el recluta piensa que camina hacia un destino desconocido, totalmente huérfano de afecto. Así lo expresa en las memorias:

En aquellos momentos horribles, de cruelísima incertidumbre, turbado por trágica angustia, carente de unos brazos familiares para sellar un fuerte adiós, sin manos amigas para estrechar, he aquí que entonces, de improviso, una joven sollozante, desconocida, a quien la tristeza evidente de mi rostro debió inspirarle lástima, se me acercó para entregarme una flor de nardo; y sin que el temblor de tan profundas emociones me dejara siquiera dirigirle una expresión de gratitud, acepté aquella flor y la llevé a mis labios, entre copiosas lágrimas.

En Cuba, durante la guerra, Conangla pudo refugiarse en la oficina y la creación literaria. Así expresa claramente el poema titulado «Página de álbum», escrito en Santi-Spíritus, su ideario pacifista, su ideología nacionalista y su fe de profesión literaria, sentimientos compartidos con muchos otros soldados ${ }^{42}$ que a Cuba arribaron forzosamente. Al cameraman se le une el poeta y el ensayista:

\section{HOJA DE ALBUM}

\section{En el del amigo Miguel Urrea}

Soñador como yo, vienes de tierra donde el trabajo es credo de la vida. De allá vine también; y aquí, en la Guerra, el consuelo del Arte nos anima. Soldados de un país, no de su idea, a los dos, en el Trópico, acompaña la fiebre creadora; y no la tea, manejada por otros, en campaña.

Y pues que pluma y lápiz, Cataluña nos dice que son armas de más gloria que las armas de muerte que hoy empuña este siglo sediento de victoria, sigamos procediendo como artistas:

${ }^{42}$ Véase el testimonio de J. Gutiérrez de Gandarilla, al publicar una nota de despedida a Conangla en El Eco Montañés, de La Habana: «Vino a esta isla hacé poco más de tres años y por las mismas causas que vine yo: por la maldita guerra; somos soldados» (9 nov. 1898). 
con tus dibujos, tú; yo con mis cantos;

y así, en vez de guerreros, idealistas

seremos, del Progreso y sus encantos ${ }^{43}$.

El primer verso de la segunda estrofa se convierte en tema central, explícito, soterrado a lo largo del libro («por obligación») y surge como titular de otro poema, «Soldado forzoso»:

\section{SOLDADO FORZOSO}

Soldado por la fuerza, no en idea, a hermoso y raro mundo me trajeron.

Aquí descubro ya la poesía, y aquí en tiempo de paz ha de ser Cielo.

Mas, iay!, que el acre vaho de la muerte enturbia unos aspectos tan brillantes, y exhala emanación de sepultura, que impide en lo grandioso extasiarse! ${ }^{44}$

Después de su estadía en Santi-Spiritus, Conangla hace un retorno espiritual, y las «Memorias» reflejan su estado de ánimo y también su identificación con el paisaje cubano. "Naturaleza bella», "Aurora», "Sensitiva», son los poemas más ilustrativos.

A finales de mayo de 1896 fue trasladado a Aguacate, territorio de la provincia de La Habana, cerca del límite con la de Matanzas. Allí recibió la inspiración para uno de los poemas más impresionantes: el uso de una iglesia como cuartel, lugar de acampada y residuo de los horrores de la reconcentración:

En la nave del templo (cuartel, hoy, insolente), ya no resuenan salmos, ni rezos de creyentes.

Los altares se astillan, se agrietan las paredes. Hasta el púlpito altivo por momentos se tuerce; y cuelgan, por ex votos, fusiles y machetes.

Sólo el altar del fondo se conserva imponente.

${ }^{43}$ Traducción del propio Conangla del poema original en catalán titulado «Fulla d'album» (p. 79).

${ }^{44}$ Traducción de Conangla de su poema original «Soldat d'una nació» (p. 32). 


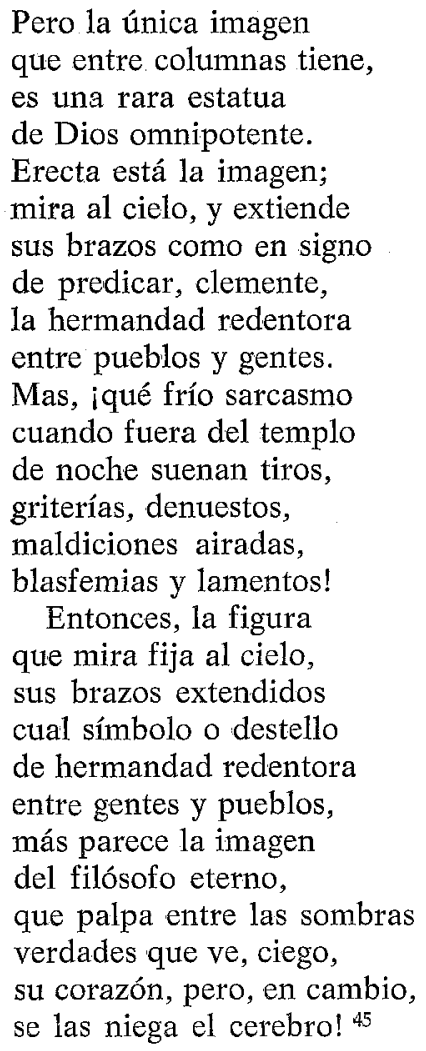

Liberal, pero creyente, Conangla reincide en el tratamiento de la identificación entre la Iglesia y el Estado, un aquelarre constituido por la manipulación del culto y las creencias, en otro poema, «La misa roja», que atrajo la atención de sus lectores a principios de siglo, uno de los más gráficos, lleno de dramatismo, color, sensaciones auditivas, pensamiento crítico y exteriorización de rabia, con una cierta dosis de repugnancia por verse forzado a participar en un espectáculo que se le antojaba obsceno. La raíz fue una misa de campaña, como las que se acostumbran celebrar en unidades militares españolas en todas las épocas. Pero en esa ocasión, lo que sería un acto más se convertiría en drama, por acontecer en plena guerra, bajo el sol tropical del mes de agosto de 1896, sufriendo todos el hacinamiento de la reconcentración y con la participación forzada del

${ }^{45}$ Traducción de Conangla del original «Dintre la nau del temple» (p. 39). 
pueblo indefenso, los enfermos, los heridos y los oficinistas. Esta es la versión del propio Conangla:

\section{LA MISA ROTA}

Por los dedos del cura sostenida se eleva con fulgor la hostia dorada. De hinojos, la columna, bajo el sol. Las cornetas resuenan en conjunto, con notas de solemne y real tonada. Relucen bayonetas y fusiles, y más de una oración es musitada.

A derecha do oficia el sacerdote, se extienden tres hileras de barracas. Allí afuera del pueblo silencioso, mora gente infeliz, reconcentrada. Revueltos entre pobres animales, mujeres y chiquillos se arrebañan, desechos de familias que in tirano requisó de los campos con gran saña.

La descripción efectúa un ligero movimiento circular, como si estuviera enfocando una cámara (más que de cine, de televisión):

A izquierda do oficia el sacerdote, un hospital de heridos se levanta; caserón de un aspecto avejentado, de silueta ruinosa, apuntalada.

El simple edificio comienza una peculiar transformación simbólica:

De par en par abiertos sus balcones, finge una calavera, aquella casa.

Las batas blanquecinas, de pacientes, cual fuegos fatuos lucen y traspasan.

Y la «filmación» regresa al foco de la acción: la misa y la eucaristía:

Cuando ya descendió la hostia divina, el cáliz vi elevarse sobre el ara. El reflejo del Sol en vaso de oro me dejó la retina deslumbrada. 


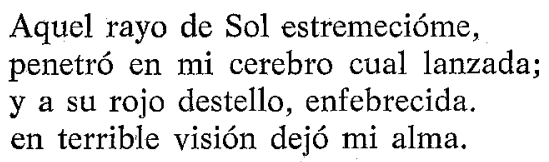

Si el poema terminara ahí no sería tan memorable, pero a renglón seguido todo cambia: la visión -la filmación- se trueca en fantasmagórica, en un surrealismo con el que se adelanta a su tiempo literario:

... Yo he visto en derredor del sacerdote de pronto aparecer muchos fantasmas, y he visto que los cuerpos descarnados contra del ara santa se lanzaban. Yo escuché la frialdad de sus chillidos, yo entendí la intención de sus palabras; y en medio del fragor, oí las voces de amigos que en la Guerra agonizaban.

$Y$ he visto a los espectros que, furiosos, al cura su ropaje le arrancaban, rasgándole iracundos el misal y arrojando las hojas destrozadas. $Y$ vi que otra invasión de aparecidos partían, en tropel, la hostia dorada, rompían en astillas el altar, y el cáliz contra el suelo rebotaban.

La acción retorna a la realidad:

Después, la multitud de descarnados se alejó por los aires en bandada, y en alto se perdieron sus chillidos, siniestros, blasfemantes, de venganza. La visión monstruosa se esfumó, dejándome la mente trastornada. Cuando libre quedé de aquel delirio, la Misa, bajo el Sol, era acabada.

Sin embargo, la tregua es transitoria:

... Al volver hacia el pueblo, en formación, sentí que mi cabeza desmayaba: El barrio de la diestra del altar creí que se movía en negra danza. 
Era todo siniestro ante mis ojos,

cual capricho de un monstruo sin entrañas.

Y termina golpeando en un paroxismo de pesadilla, donde se aúnan la ideología pacifista y la denuncia política:

Y hasta al ver, de un fortín en lo más alto, la bandera de España roja y gualda, descubrir parecióme que sus pliegues en sangre, gota a gota, se licuaban! ${ }^{46}$

La otra notable muestra de este tipo de poema (que es al mismo tiempo una fiesta de lenguaje y expresión de su pensamiento) es «El incen. dio», en el que trata de reflejar la dureza de la vida en aquel lugar al que la guerra golpeaba tangencialmente. La guarnición estaba cerca del ingenio Rosario, uno de los más importantes de la isla. En octubre de 1896, tras un encuentro entre mambises y fuerzas españolas, se propagó un monumental incendio ${ }^{47}$ en la campiña, que amenazó a la población. Conangla lo contempló desde el campanario de la iglesia-cuartel:

\section{EL INCENDIO}

E1 vigor de la caña, que gozosa mecía, a prima noche, el dulce fruto sin riesgos ni peligros, crepitante retuerce entre las llamas su cosecha!

E1 rumor imponente del incendio confunde, con su impulso, maldiciones y tiros de las tropas que se escapan.

Las bestias, azoradas, aullantes o en relinches de horror, corren sin tino, buscando una salida salvadora...

${ }^{46}$ Traducción de Conangla de su original «La missa roja», p. 50. Fue publicado enteramente en la revista Joventut el 5 de mayo de 1904 (año V, núm. 221, p. 292). Allí conserva la fecha de 1897 en Aguacate, y se menciona expresamente que pertenece al libro en prensa Elegia de la guerra.

${ }^{47}$ No era un incidente aislado, sino pauta constante en la guerra, íntimamente relacionada con la política de la reconcentración, la que el mismo Weyler justificaba como causa de los frecuentes fuegos provocados: «¿Quiénes eran los que habían incendiado? ¿Eran los soldados españoles? Yo lo niego... los insurrectos eran los incendiarios, y ésta fue la causa de la reconcentración y de la miseria... al invadir los insurrectos esos pueblos que incendiaban, las familias que residían en ellos tenían que refugiarse» (Diario de Sesiones del Senado, 1 mayo 1898). 
La palmera gentil, irradiada por las lenguas de fuego que la ahogan, sus palmas al Cielo, suplicantes, cual si al Cielo clamara, adolorida.

Y el Cielo es tenebroso; ni la Luna a salir se atrevió; y ni una estrella en la comba imponente se destaca.

Abajo, reunidas en contorno de la Iglesia y su torre, las casuchas del pueblo asustadizo se recogen.

En torno a las campanas en silencio, frente a los ventanales, encendidas parecen nuestras caras, a la roja resplandor del incendio que contemplan.

Y yo, con mayor fiebre por la sangre que acude a mi cerebro, presurosa, el rostro siento arder y tembloroso me agito entre ideales de protesta.

iAh, monstruos legendarios!, vuestras obras, cuán leves me parecen, al ardiente resplandor de las llamas que en el campo abrió un trozo de infierno, a flor de tierra!

Ni el bíblico Satán, desde su trono, presidiendo entre furias los martirios de pobres condenados -cual supone la mente en turbación-, muestra el encono del genio de la guerra destructora, cuando airado desata sobre el mundo regueros de miserias y venganzas.

Reparad, combatientes obcecados, cómo sois instrumentos de ese monstruo: Cuanto abarca la vista, lo devora e1 fuego aterrador... Ya no os bastaban los actos de inclemente sacrificio contra propios hermanos; no os cumplían los hechos iracundos contra el hombre; vuestro ser se encanalla hasta privarle del fruto a la más pródiga Natura. 
El odio que sentís, a borbotones lo arrojáis sin piedad sobre la tierra; la tierra piadosa, que produce con el amor sublime la gran madre!

¡Oh, casta de Nerones, vil ralea que saciáis vuestras ansias destructoras con actos de rencor! ¿Cuál es el premio que os impele en la ruta miserable de la guerra feroz?

$$
\text { Y tú, misterio, }
$$
ignorada Entidad en quien radica el dominio total, $i$ cómo permites, si inmenso es tu poder, esos escarnios? ¿Por qué consientes, di, que en mente humana germinen estos crímenes horrendos si puedes impedirlo? :Cruel sarcasmo! 48

Después, en otro contrapunto, en sus «Memorias» (al igual que en el poemario) huye del infierno desolado de la guerra colonial, y retorna espiritualmente a su tierra y al recuerdo de su padre, quien falleció cuando Conangla estaba en la guerra. Enfermo de la fiebre amarilla (que mató más soldados españoles que las propias acciones de los independentistas) en Aguacate, se recuperó en el hospital habanero de Las Animas. Así compuso los poemas (precisamente los que provocaron la referencia cinematográfica de Rovira i Virgili) titulados «Soñando con mi tierra», «Recuerdos invernales», «La retama», «Remembranza» y «Padre».

E1 7 de diciembre de 1896, Antonio Maceo, «Titán de Bronce», líder de la lucha de liberación de Cuba, cayó en combate. Como era de esperar, después de las celebraciones decretadas por las autoridades españolas, la guerra entró en una fase todavía más dura. Conangla compuso otros poemas todavía más meditativos. Con el título general de «Navidad», incluyó estas composiciones: «La tradición», «El filósofo», «El soldado» y «El poeta». Esta última repasa su fugaz existencia:

\section{EL POETA}

Años veinte de mi vida,

Navidades luminosas de mi ayer:

en vano os llama y convida

la voz más impaciente de mi ser.

${ }^{48}$ Traducción de Conángla del original titulado «L’incendi» (pp. 42-44). 
¡Cuán lejanos estáis! Su imagen pura conservo en la memoria, que fundé en una lágrima perjura

la inmensidad penosa de una historia.

iRetornad, pues, ingenuas a mis labios, oh preces infantiles;

devuélveme los resabios, oh $\mathrm{Fe}$, de mis creencias pueriles!

La Navidad del poeta, hoy no la puedo cantar, una nave atrevida y obsoleta me la hurtó tras del mar.

Costas de mis añoranzas: ¿me acogeréis venturoso? ¿O perdidas serán mis esperanzas del hado en to insondable misterioso?

Oh Navidad, Navidad: no sé cómo bendecirte. ¡Mi canto podría herirte con estrofas de impiedad!

¡Tu nombre causa en mí tanta ansiedad! 49

Durante su servicio como ayudante de enfermería, Conangla aprovechaba el tiempo para completar su serie de poemas de inspiración local. «Aurora», «Un rayo de sol», «Tropical», «Insomnio», «La luciérnaga»y «Dolencia espiritual» son los más representativos, al igual que «Soldado de una nación», la composición ya mencionada. «La guitarra» es un poema que está inspirado en las reuniones de ocio entre los soldados. Los más dotados cantaban canciones de su tierra o las improvisaban allí mismo:

No sé qué tiene de extraño, en sus cuerdas, la Guitarra, que nos transporta el espíritu a regiones de añoranzas.

No sé qué tiene de extraño, en sus cuerdas, que embriagan con alegrías llorosas que cosquillean el alma.

\footnotetext{
${ }^{49}$ Traducción de Conangla del original «El poeta» (p. 64).
} 
$\mathrm{Y}$ si al mágico instrumento, oído en tierras lejanas, del soldado añoradizo las canciones se entrelazan.

No sé, entonces, qué de extraño tiene en su son la guitarra, que al corazón nos parece que se dirige y nos habla, con acentos amorosos de consuelo y de esperanza; $\mathrm{y}$ humedece nuestros ojos con emociones tan sanas, que esfuman nuestros recuerdos $\mathrm{y}$ apaciguan nuestras ansias de indignación encendidas contra las gentes malvadas que explotan nuestra inocencia, nos envilecen y engañan! ${ }^{50}$

Conangla fue trasladado finalmente a Puentes Grandes y a La Habana en junio de 1897, donde se encontraba cuando terminó la guerra, después de la rendición de las tropas españolas, a continuación del desastre de la flota de Cervera en la bahía de Santiago de Cuba. Aprovechó el tiempo, antes de embarcarse, en ajustar algunos versos más en su escritorio del Castillo de La Fuerza - que luego serviría de cuartel de ocupación de las fuerzas norteamericanas y con el paso del tiempo se convertiría en Biblioteca y Archivo Nacional-, que evolucionarían en unos de los mejores poemas de Elegía de la guerra: "La guerra y la paz», "Patrioterismo» y «Grito de paz». La primera es una comparación onírica, que recuerda la estructura de «La misa roja»:

Las he visto, ambas, en sueños, cada cual con su cohorte.

Una vestía de luto;

la otra, con manto de Corte.

Una, triste, se abatía

y abocaba su partido

a un infierno de miserias, y al desastre de sus hijos.

${ }^{50}$ Traducción del original por Conangla (p. 45). 
La otra, hermosa, sonriente, sembrando ciencia a raudales, cimentaba industrias nuevas, arraigaba más las artes, fortalecía el trabajo, multiplicaba el comercio, y a sus hijos bautizaba en el templo del Progreso.

Las dos reinas se miraron celosas de sus cohortes: una vestía de luto; la otra, con manto de Corte.

El partido de la Guerra se pasó al otro partido. Y la Guerra se quedó sola ya $\sin$ reinado y $\sin$ hijos.

Y la Paz, bella y sonriente, juntó amigos y conversos y en el templo de la Vida celebró tan gran Suceso.

«Patrioterismo» es un clásico ejemplo de denuncia de los ideales nacionalistas manipulados que llevaron al desastre de 1898:

\section{Corriente fementida}

que invade las naciones

y disfraza la gloria de la Vida con careta fingida

de doradas visiones.

Tenebroso, insensato sentimiento, que impone, donde quiera, contizar el color de una bandera al precio más sangriento.

Fanatismo que en mares de armonía y de humanos afectos sepulta las ternezas de poesía $\mathrm{y}$ hace flotar los limos más abyectos.

Sentimiento engañoso de malvados que defienden bajezas y asesinan soldados. 
Si un día, de repente, presa de noble ira, transformase este mundo un genio ardiente, icómo harían las madres un pire de implacable escarmiento!

«Grito de paz» reúne la nostalgia por la tierra nativa, el recuerdo de sus padres y los sentimientos pacifistas:

Oh, Europa, en mi destierro suspirada!

Oh, Iberia, por do cruzan mis recuerdos!

Oh, mi dulce y querida Cataluña, la tierra de mis ansias y mis duelos!

Oh lugares hermosos donde alienta la Villa de mi infancia y de mis sueños! Oh rostros sonrientes que me aguardan! Or lar, oh madre mía que venero!

Por fin, si el rudo Atlántico permite que sus fauces no engullan a mi cuerpo, volveré a divisar risueñas playas, reviviré entre abrazos y entre besos, se inundará mi ser en dicha pura, escucharé palabras de consuelo!

iMas, ay, que la figura venerable de mi Padre querido no ha de verlo; y amargará tan dulces bienvenidas la orfandad de aquel rostro tan austero!...

\section{DESPEDIDA Y PRELUDIO DEL RETORNO}

Finalmente, justo en el embarco, cuando el retorno a Cataluña es ya cuestión de horas, Conangla da un adiós que luego se convertiría en un «hasta luego». Los poemas titulados «Adiós a Cuba» y «A Cuba libre» están dedicados a la que sería su patria adoptiva. De ellos diría Rovira i Virgili: «Siente justas simpatías por los insurrectos cubanos, reconociendo la legitimidad de las aspiraciones por cuya consecuencia hicieron ondear la bandera de combate... La generosidad del poeta, proclamando, frente a un españolismo caduco, el derecho de Cuba a ser independiente, es una de las más simpáticas notas de Elegía de la guerra» ${ }^{51}$. En el primero de

\footnotetext{
${ }^{51}$ La Avanzada, 28 mayo 1904.
} 
estos poemas se encuentran resumidos sus sentimientos sobre la guerra, al lado de su admiración por la geografía cubana:

\section{ADIOS A CUBA}

No obstante la profunda impaciencia que siento por volver a tierra ansiada, te dejo con pesar, hija del Trópico, Isla de ardiente sol. Cuba galana.

Te dejo con pesar; pues con cariño de ti nobles efectos ya me hablan; y también llevo impresas emociones de tu ser y tus cosas en mi alma.

Te dejo con pesar; pues mi conciencia rebelde común tú, por igual causa como tú en opresión se consumía, como tú, independencia reclamaba ${ }^{52}$.

$Y$ cómo no quererte, si en tu seno gran número de amigos ya descansan!

Si por lucha tenaz y vergonzosa traído fui a la fuerza hasta tus playas; y el mandato español, en su ceguera a tratarte con odio me impulsaba, yo, atento a mi sentir, día por día más en secreto en tu favor clamaba; y desmanes y furias me dolían de las calumnias nuestras, como al alma me llegaban también las punitivas acciones de las fuerzas rebeladas.

¡Oh, la guerra maldita, tenebrosa, que embrutece al soldado en represalias! ¿Malditos los que atizan los ejércitos cual jaurías famélicas y airadas! ¿Y maldita justicia de los pueblos que pesa las razones con matanzas!

${ }_{52}$ Véase la afinidad con estos versos de Angel Guimerá (Santa Cruz de Tenerife 1845-Barcelona 1924), otro de los artífices del modernismo catalán:

«Hijos de la tierra cubana que los grilletes supisteis destrozar, rogad por vuestra hermana que añora la Libertad.»

(Versión castellana de Joaquim Molas y Josep M. Castellet en Ocho siglos de poesía catalana [Madrid: Alianza, 1969], p. 368). 
¿Por qué la humanidad por malos guías

llevar se deja, cual ovejas mansas, y es instrumento de pasiones ciegas y no quiere evitar acciones bajas, y no escucha la voz de rebeldía contra leyes injustas, fratricidas, por soberbia ambiciosa preparadas?

-Ya la lucha ha cesado, y ya clarea para ti y mis hermanos la alborada serena, radial del nuevo día que a todos ha de darnos luz y calma.

¡Bella es la Paz, de pueblos redentora! ¡Bello es el día en que la Guerra acaba!

\section{A CUBA LIBRE}

¡Luce de nuevo tus galas, oh Cuba del Sol ardiente: remoza ya los encantos de tus brillantes vergeles; canta otra vez tus canciones que tienen dulzor de mieles; despierta las armonías de tus sinsontes noveles; trenza con rayos de Luna tus fantasías celestes; Forma con tan bellos dones el himno más atrayente, y goza feliz el día tan esperado y solemne en que, de tu carcelero, libre, al fin, pudiste verte!

¡Mas, cela bien de tu dicha, oh Cuba del Sol ardiente; que hallar podrías, acaso, unas rejas aún más fuertes! ¡Cuida de tus alas, Cuba! ¡Elévate. Sé prudente!

El último poema del libro («Zarpando hacia mi tierra») es un canto lírico al mar que lo acerca a la península y las costas dejadas atrás en Ca- 
taluña. En las «Memorias», la travesía ${ }^{53}$ por el Atlántico le sirve para comentar sobre las preocupaciones de los militares ante un futuro incierto, rememora las canciones del soldado repatriado, los juegos de cartas, los funerales en el mar de los últimos enfermos de la fiebre amarilla. El 25 de noviembre de 1898 llegó el «Satrústegui» a la bahía de Cádiz. En otros puertos españoles desembarcarían miles de repatriados en estado patéti$\mathrm{co}^{54}$. Por tren, Conangla atravesó todo el sur y el levante, y dejó en sus «Memorias» estos párrafos que representan —además de su fina sensibilidad literaria, muy en consonancia con el tono y el contenido del 98 de Azorín y Machado- su sincera ideología fraternal hacia todas las tierras de España:

Crucé por las resecas llanuras de la Mancha, escenario de la inmortal concepción cervantina. Recreé mi visión, al paso de las evocadoras campiñas de Elche y de Alicante, tachonadas de palmas datileras. Admiré las bien trazadas acequias morunas y los jugosos naranjales de las famosas huertas valencianas. Atravesé el Ebro, en su cansada desembocadura de la individualísima Tortosa. Me detuve unas horas en la augusta Tarraco, preceptora clásica de mis primeros romanticismos poéticos y educadora, más tarde, de mis convicciones idealistas contra toda clase de tiranías, despotismos, injusticias y atentados a los inmanentes derechos y respetos naturales de personas, familias, pueblos y naciones.

Y cambiado ya en Tarragona mi uniforme de rayadillo por la indumentaria de paisano, cerré, por fin, aquel periplo fatigoso de mi primera juventud, con el arribo anhelado a Montblanc.

El poeta tardaría nada más siete años en decidirse a emigrar a Cuba, donde se quedaría a vivir hasta su muerte, en 1965, después de una larga

${ }^{53}$ Este episodio, relatado en las «Memorias», ha servido de frecuente epitafio o inicio para obras históricas que tienen como tema el desastre colonial o la posterior meditación sobre el presente y porvenir espãñol efectuado por la Generación del 98. En el contexto catalán, podría servir como gráfica (y cinematográfica) ilustración literaria a los primeros pasajes de La ciutat cremada (1976), de Antoni Ribas, la película que representó el renacimiento del cinema catalán.

${ }^{54}$ He aquí un retrato clásico y antologizado hasta la saciedad: «Formaron las tropas con el traje de viaje, haraposo y sucio, produciendo un efecto desastroso. Procedióse a la limpieza de los soldados bañándolos en agua tibia. Después se les dio un traje completo» (El Heraldo, La Coruña, 11 septiembre 1898). Unos meses. más tarde, tras el trauma del momento, todo volvería a la normalidad. Baroja dejaría estas líneas clásicas: «El Gobierno, que, como la mayoría de los gobiernos, no tenía idea del país, creía que, al saber la derrota, los españoles iban a hacer la revolución, y no pasó nada. Al salir la noticia en Madrid, la gente se fue a los toros y al teatro, tan tranquila, sin hacer, no ya protesta, ni siquiera comentarios. Entonces fue cuando dijo Silvela que España no tenía pulso» («Desde la última vuelta del camino», Obras, vol. VII, Madrid, 1949). 
vida de periodismo y de trabajos por la independencia de Cataluña. Allí quedarían, para siempre incrustados en su historia cultural, sus versos modernistas. Son poemas catalanes sin renunciar a la universalidad; fueron escritos en su lengua original, abiertos a la traducción. Fueron redactados en un lenguaje innovador, colorista y sonoro, cinematográfico (como diría Rovira), que se adelantó incluso al vanguardismo y que predecía el necesario remanso del posmodernismo al estilo latinoamericano ${ }^{55}$. Fue su contribución honesta: poesía catalana, modernista, marcada por el desastre del 98, generada en América.

\footnotetext{
${ }^{55}$ Véase su producción posterior, sobre todo Eternal.
} 
